\title{
INHOMOGENEOUS PLASTIC DEFORMATION AND FRACTURE OF DOUBLE REDUCED THIN PLATES
}

\author{
Emil Spišák, Janka Majerníková, Dávid Bogdan, Tomáš Sleziak, Marek Čižmár
}

Original scientific paper

This paper discusses causes and consequences of plastic deformation of packaging sheets which are nowadays used in a wide range of applications. The article deals with a specific inhomogeneity and localization of plastic deformation which is analysed in detail. For material testing, uniaxial and biaxial tensile test was used and the results were also compared and evaluated. In the last part of this paper microstructure of material was analysed by localized deformations.

Keywords: double reduction; plastic deformation; tensile tests; thin plates

Nehomogena plastična deformacija i lom dvostruko oslabljenih tankih limova

Izvorni znanstveni članak

Ovaj članak govori o uzrocima i posljedicama plastične deformacije tankih limova koji su trenutno u širokoj uporabi. Članak se bavi specifičnom nehomogenosti i lokalizacijom plastične deformacije koja se detaljno analizira. Za ispitivanje materijala rabljeno je jednoosno i dvoosno vlačno ispitivanje, a rezultati su također uspoređeni i ocijenjeni. U posljednjem dijelu članka analizirana je mikrostruktura materijala kod lokaliziranih deformacija.

Ključne riječi: dvostruko oslabljenje; plastična deformacija; vlačna ispitivanja (čvrstoće); tanki limovi

\section{Introduction}

Forming of thin plates is characterized by a phenomenon where there is a specific inhomogeneity which causes and effects are analysed in this paper. Generally we studied material (thin plates) divided by method of production, whether it is a simple reduced or double reduced plate (DR). Made plate thickness depends on the method of production and produces in the interval $(0,13 \div 0,50 \mathrm{~mm}$. $)$. In the process of production during cold rolling tandem mill there is a significant strain hardening of the material. Adverse effect which is strain hardening after plastic deformation of the material is removed by continuous (CA) or bench annealing (BA). The modified material has much better mechanical properties and fine-grained structure. On the modified material is applied protective coating of tin which combines several advantages such as excellent formability in combination with strength wholesomeness and corrosive resistance [1].

DR tinplate is currently most frequently evaluated by tension test (uniaxial tensile test). Mechanical and plastic properties achieved through this test, however, show severe scatter of the measured properties. Significantly high scatter is seen when considering material plasticity that is characterized by material elongation. The measured elongation properties of DR tinplate achieved by uniaxial tensile test tend to be very low (starting 0,2\%). In the paper we tried to determine what the behaviour of DR tinplate is in case of biaxial tensile test by hydrostatic bulging and to analyse the root causes of nonhomogenous plastic deformation with subsequent disruption of tested sample during tension test.

\subsection{Local plastic deformation and its progress}

Plastic deformation of most closely specified material, can be broadly classified and dealt with at three levels, namely the micro, meso and the macro level. The majority of low-carbon sheet at the deformation processes of material after the initial phase of the so-called uniform deformation starts loss of stability and localization of deformation resulting from the plastic behaviour of the material which is illustrated by local narrowing and thinning samples (Fig. 1). Reducing the width of the sample takes up time as it is the narrowing (Fig. 1a) appears the so-called loss of stability sheet (Fig. 1b) the wide of sample which depends on the thickness of the plate. Condition of localization of plastic deformation is a decrease in the value of load transmitted through the sample in a direction perpendicular relative to the length of the sample. The loss of stability of the material strain localization in the form of shear bands (Fig. 1c) starts at the moment when the load reaches the maximum size [2, 3]. Model of geometrical inhomogeneities of material is illustrated in Fig. 2.
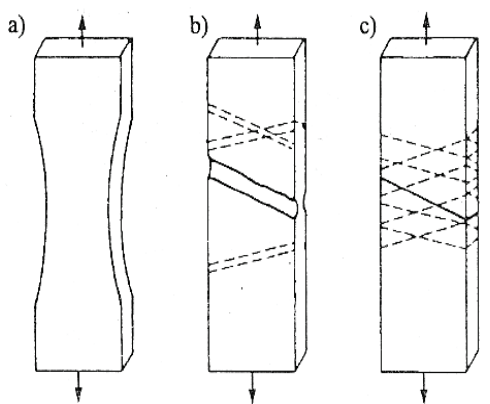

Figure 1 Ways to loss of stability, a) the loss of stability, b) the loss of stability steel sheet, c) the general loss of stability [2].

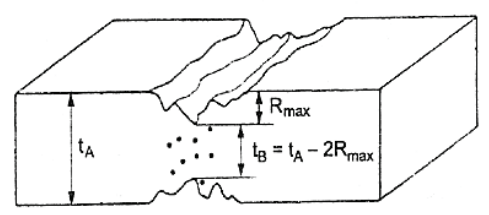

Figure 2 Model of geometrical inhomogeneities of material [2]. 
Methods for localization of deformation as well as the conditions of loss of stability sheets were described by many authors. Generally have been accepted threebasic models of loss of stability of the model that we include model of diffuse thinning (Swift) [4], model of local thinning (Hill) [5] and model of initial inhomogeneities in the material (Marciniak) [6].

Deformation proceeds at decreased stress level known as the lower yield stress accompanied with inhomogeneous deformation. The specimen is divided into regions where the strain is relatively high (Lüders strain) and regions which are still elastic. The distinct plateau in the stress-strain curve is characterized by the propagation of Lüders bands. The propagation of Lüders bands is influenced by many factors including crystal structure, grain size, composition and microstructure, shape and stiffness of the testing sample, strain rate and the type of loading. Experimental study of local deformation has been described previously by the authors (Zhang) and (Jiang). It was fond that the load at the beginning of Lüders band is lower than the total tension. Generally this phenomenon is important in the process of deformation of the material $[7,8]$.

When observing localization of plastic deformation at different levels, namely micro, meso and macro level the main meaning is placed on micro level of plastic deformation. By observing effects and causes of deformation at various levels deal the source [9]. The generally known knowledge of plastic deformation and their effects in other words fracture of materials are cases of local plastic deformation in the so-called point. These problems have a common fracture feature that involves knowledge of the evolution of their material constituents in addition to their behaviour in service. Localization of plastic deformation is concentrated in shear bands of different sizes involving the shear and rotation of the crystal lattice. Structural elements such as grains and grain boundaries contribute to this phenomenon and knowledge involving these problems are summarized in sources $[10 \div 12]$. Formation of shear bands of different sizes is essential for all plasticity deformed solids. The term meso volume introduces the following factors of deformed continuum called stress concentrators namely:

- Nucleation and development of plastic shear bands,

- Initiation and propagation of internal rotation of the structural elements,

- Slipping systems of the individual crystal and their activation under loading [13].

Elasto-plastic deformation of materials has been traditionally analysed using continuum mechanics, simulated deformation and fracture of materials at the macroscopic description. Experimental outcomes show that evolution of internal microstructure in materials plays very important role [9]. It is for this reason the dislocation theory has been used to analyse strain hardening, formation of substructure through deformation and flow characteristic curves associated with the development of the internal microstructure of a given material [9]. Material after plastic deformation in its meaning is considerate to be a hierarchical system of elements with their own organizational structure of the system. Macroscopic reflect about this problem discusses above macroscopic characteristics of the material. Fracture of material or loos of functional properties of the material also means inability to resist external influences [9].

Micro level of plastic deformation discusses about properties of single crystal after tensile leading where there is slipping mechanism in several ways. To determine the scale was introduced so-called Burgers vector. General knowledge of plastic deformation can be obtained in simulation of the process which involves elastic deformation, plastic deformation, formation of structural defects and the formation of cracks in the internal construction of material $[14 \div 17]$. On the deformation and fracture of $\mathrm{Fe}-\alpha$ single crystals and stress-strain curve has a significant influence so-called Frenkel defects. The Frenkel defects are relatives of interstitial atoms and vacancies and play an important role to understanding of the physical and mechanical properties of solids. Have been introduced for simulations at selected locations in the crystal so that there is a removal of an atom from its original position in the atomic lattice of metal and has been creating so-called interstitial void in the structure $[18 \div 21]$.

\section{Material for the experimental research}

For experiments were used bench annealed packaging steel sheets. Quality of sheets were TS 480 BA, thickness $0,155 \mathrm{~mm}$. Steel plates were made by simply rolling and then rolled double reduction to the required size. In the process of production these plates are bench annealed to remove strain hardening after plastic deformation. Most of the current packaging sheets are further processed by drawing (drawing two-pieces containers, lids, twist caps, etc.). Samples were taken in the rolling direction $\left(0^{\circ}\right)$ and the direction perpendicular to the rolling direction $\left(90^{\circ}\right)$. The chemical composition of the material is given in Tab. 1.

Table 1 Chemical composition of the material TS 480 BA expressed as

\begin{tabular}{|c|c|c|c|c|c|c|c|}
\hline $\mathrm{Fe}$ & $\mathrm{C}$ & $\mathrm{Si}$ & $\mathrm{Mn}$ & $\mathrm{P}$ & $\mathrm{S}$ & $\mathrm{Cu}$ & $\mathrm{Al}$ \\
\hline 99,26 & 0,107 & 0,020 & 0,368 & 0,017 & $<0,002$ & 0,031 & 0,056 \\
\hline $\mathrm{Cr}$ & $\mathrm{Mo}$ & $\mathrm{Ni}$ & $\mathrm{V}$ & $\mathrm{Ti}$ & $\mathrm{Nb}$ & $\mathrm{Co}$ & $\mathrm{W}$ \\
\hline 0,010 & 0,014 & 0,014 & 0,008 & $<0,002$ & 0,016 & 0,027 & 0,044 \\
\hline
\end{tabular}

For determine the chemical composition of the material was used the mobile device Spectrometer Belec Compact Port.

\section{Experiment}

For the purpose of detection the mechanical properties of tested plates was making a uniaxial tensile test (Figs. 3 and 4). The resulting samples were difficult to evaluate because the violations occurred many times out of samples measured section. The samples were observed that the plastic deformation occurs in the measured distance limited to certain areas. Uniaxial tensile test was carried out on the device TIRA test 2300 .

For this test conditions and the shape of the specimen indicate standards STN EN ISO 6892-1. 
Planar anisotropic properties of the material TS 480 $\mathrm{BA}$ in direction $\left(0^{\circ}\right)$ and $\left(90^{\circ}\right)$ obtained from uniaxial tensile test are shown in the Tab. 2.

Table 2 Mechanical properties tested steel sheets identified by uniaxial tensile test

\begin{tabular}{|c|c|c|c|c|c|}
\hline $\begin{array}{c}\text { Sample } \\
\text { number }\end{array}$ & $\begin{array}{c}\text { Additional } \\
\text { information }\end{array}$ & $\begin{array}{c}\text { Thickness } \\
/ \mathrm{mm}\end{array}$ & $R_{\mathrm{p} 0,2} / \mathrm{MPa}$ & $R_{\mathrm{m}} / \mathrm{MPa}$ & $A_{50} / \%$ \\
\hline $56 \|_{1}$ & TS $480 \mathrm{BA}$ & 0,155 & 497,0 & 513,6 & 3,66 \\
\hline $56 \|_{2}$ & TS $480 \mathrm{BA}$ & 0,155 & 507,3 & 520,4 & 6,35 \\
\hline $56 \|_{3}$ & TS 480 BA & 0,155 & 490,9 & 517,5 & 5,07 \\
\hline$\div 56 \|$ & TS 480 BA & 0,155 & 498,4 & 517,17 & 5,03 \\
\hline $56 \perp_{1}$ & TS 480 BA & 0,155 & 558,5 & 570,1 & 0,57 \\
\hline $56 \perp_{2}$ & TS 480 BA & 0,155 & 550,9 & 594,7 & 0,83 \\
\hline $56 \perp_{3}$ & TS 480 BA & 0,155 & 544,4 & 590,0 & 0,39 \\
\hline$\div 56 \perp$ & TS 480 BA & 0,155 & 551,27 & 584,93 & 0,597 \\
\hline $65 \|_{1}$ & TS 480 BA & 0,155 & 431,5 & 496,4 & 5,42 \\
\hline $65 \|_{2}$ & TS 480 BA & 0,155 & 439,2 & 489,4 & 5,53 \\
\hline $65 \|_{3}$ & TS 480 BA & 0,155 & 475,7 & 487,0 & 4,99 \\
\hline$\div 65 \|$ & TS 480 BA & 0,155 & 448,8 & 490,93 & 5,31 \\
\hline $65 \perp_{1}$ & TS 480 BA & 0,155 & 526,9 & 563,8 & 1,81 \\
\hline $65 \perp_{2}$ & TS 480 BA & 0,155 & 549,9 & 564,4 & 1,49 \\
\hline $65 \perp_{3}$ & TS 480 BA & 0,155 & 545,4 & 570,8 & 2,31 \\
\hline$\div 65 \perp$ & TS 480 BA & 0,155 & 540,7 & 566,33 & 1,87 \\
\hline
\end{tabular}

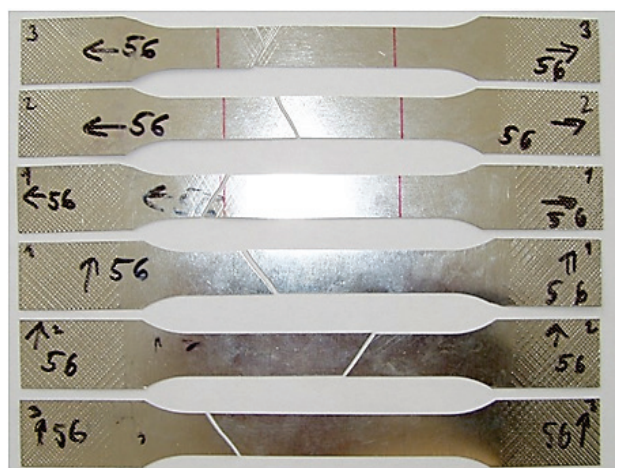

Figure 3 Rupture of samples No. 56 after uniaxial tensile test

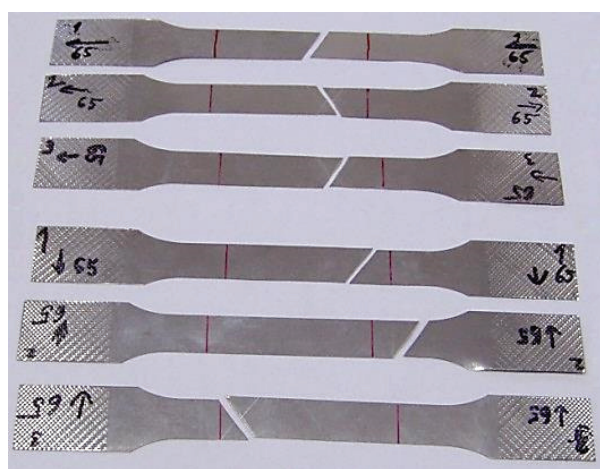

Figure 4 Rupture of samples No. 65 after uniaxial tensile test.

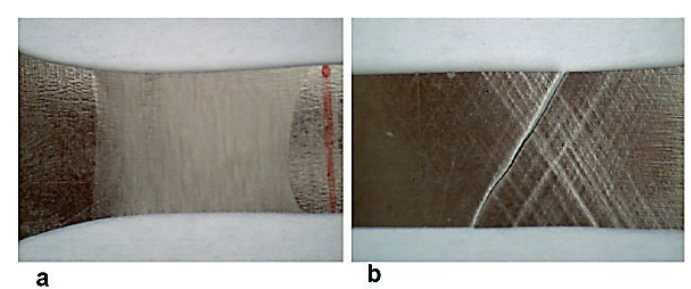

Figure 5 Rupture of samples after uniaxial tensile test of TS 480 BA

For these sheets that show Lüders band slip at uniaxial tensile test it is problematic to determine the value of maximum uniform deformation. As for continuous annealed samples (Fig. 5a) it is showed a strain creation in specific sample sections. It starts in one place suddenly stops and passes into a completely

different sample place. In the case of test samples that were batch annealed there have been ruptures in all samples during local strain sheet without any expansion of strain measured in the whole length of tested samples (Fig. 5b).

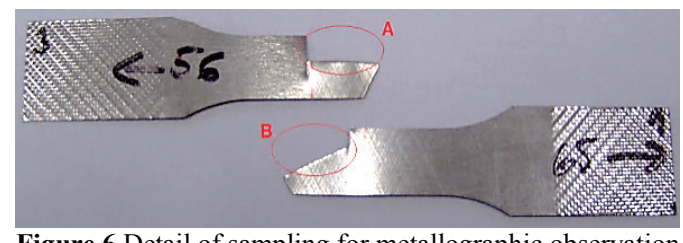

Figure 6 Detail of sampling for metallographic observation

In the next part was performed metallographic observation structure of material. Samples were observed and evaluated using a light microscope GX 71 Olympus. Samples were taken from deformed parts after uniaxial and biaxial tensile tests. Fig. 6 show places marked with $\mathrm{A}$ and $\mathrm{B}$ selected for metallographic observation.

For the purpose of detection the mechanical properties of tested plates was making a biaxial tensile test. The sample after failure is documented on the Figs. $7 \mathrm{a}$ and $7 \mathrm{~b}$. The deformed specimens were clearly visible slip bands on deformed area. Planar anisotropic properties obtained from this test are shown in the Tab. 3 .

Table 3 Mechanical properties tested steel sheets identified by biaxial tensile test

\begin{tabular}{|c|c|c|c|c|c|c|}
\hline $\begin{array}{c}\text { Sample } \\
\text { number }\end{array}$ & $\begin{array}{c}\text { Additional } \\
\text { information }\end{array}$ & $\begin{array}{c}\text { Thickness } \\
/ \mathrm{mm}\end{array}$ & $\begin{array}{c}R_{\mathrm{p} 0,2} / \\
\mathrm{MP}\end{array}$ & $\begin{array}{c}R_{\mathrm{m}} / \\
\mathrm{MPa}\end{array}$ & $A_{50} / \%$ & $\begin{array}{c}h_{\text {dome }} \\
/ \mathrm{mm}\end{array}$ \\
\hline $56_{1}$ & TS 480 BA & 0,155 & 559,9 & 591,1 & 5,3 & 11,4 \\
\hline $56_{2}$ & TS 480 BA & 0,155 & 536,4 & 599,4 & 7,8 & 13,8 \\
\hline $56_{3}$ & TS 480 BA & 0,155 & 536,4 & 574 & 3,57 & 9,3 \\
\hline$\div 56$ & TS 480 BA & 0,155 & 544,2 & 588,2 & 5,55 & 11,5 \\
\hline $65_{1}$ & TS 480 BA & 0,155 & 505,1 & 553,4 & 6,80 & 12,9 \\
\hline $65_{1}$ & TS 480 BA & 0,155 & 516,8 & 559,6 & 6,6 & 12,7 \\
\hline $65_{1}$ & TS 480 BA & 0,155 & 505,1 & 546,4 & 5,61 & 11,7 \\
\hline$\div 65$ & TS 480 BA & 0,155 & 509 & 553,1 & 6,33 & 12,43 \\
\hline
\end{tabular}

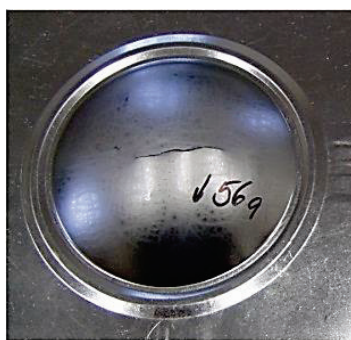

a

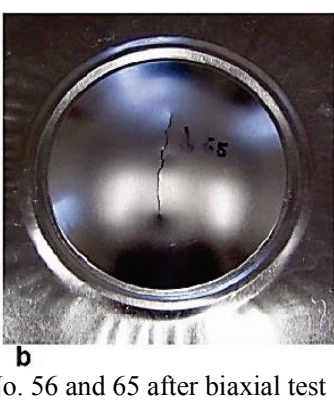

Biaxial tensile test was performed on the equipment for hydraulic bulging (Bulge test). The test plate is clamped between the bottom plate and die with a diameter $80 \mathrm{~mm}$. The blank holder prevents pulling material through the rib located in die. Fluid pressure is used for deformation and subsequent burst of the sample. Measure of the plastic properties of the test plate is height of dome and crack shape after violation of dome. From biaxial tensile tests are evaluated parameters such as yield strength $R_{\mathrm{e}}$, tension $R_{\mathrm{m}}$, total elongation of sample $A_{50}$ and height of dome $h_{\text {dome. }}$. For this test conditions and calculation of parameters are described in the source [22]. 


\section{Experimental results and discussion}

From obtained results can be said that the uniaxial tensile test was difficult to evaluate and causes have been described in the experimental section of this paper. Measured mechanical properties mainly in continuous annealed sheets were characterized by significant differences in the values of tensile strength and elongation. It can be stated that more favourable test for the evaluation of packaging sheet is biaxial tensile test.

From metallographic observation of the microstructure was analysed packaging sheet TS 480 BA. After uniaxial tensile test in the direction $\left(0^{\circ}\right)$ microstructure showed significantly elongated grains in rolling direction which is the result of the double reduction (Figs. $8 \div 11$ ).

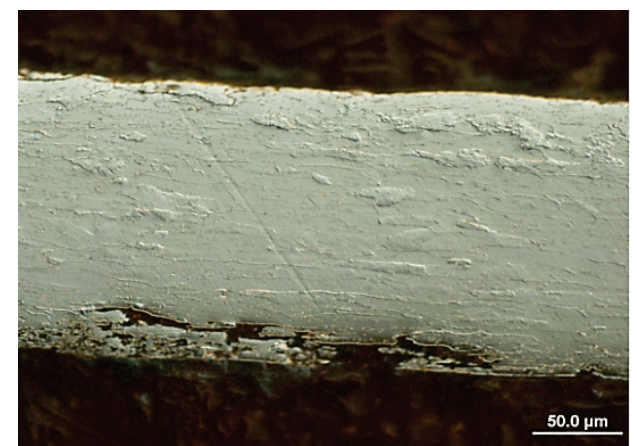

Figure 8 Microstructure of TS 480 BA, Sample No. 56

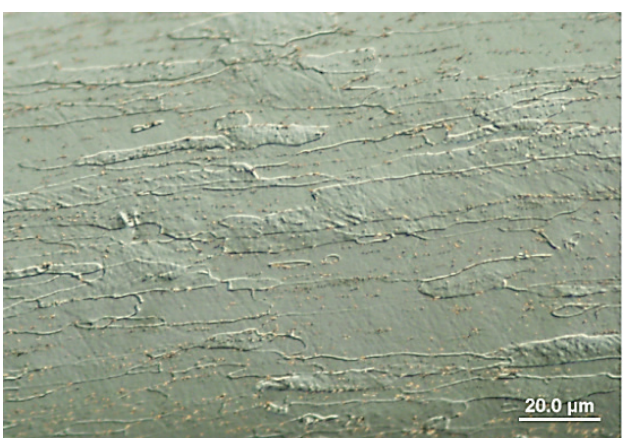

Figure 9 Microstructure of TS 480 BA, Sample No. 56

Localization of deformation and fracture of samples for tensile test can be explain by Marciniak theory according to which the localization of deformation occurs in areas with a strong inhomogeneity of the material. Inhomogeneity of the material can be represented by changing the surface microgeometry and internal inhomogeneity of the material when the samples observed deformation dandruffs and a lot of surface defects. The main role in this process played a depth of defects (Figure 8 ). At these locations and the coupling of base material with deformation dandruff were observed non-metallic inclusions - oxides the presence of which depends on the material conditions of annealing (Fig. 8).

Despite very low values of the elongation, it was found that the failure is typical plastic (Fig. 11). From the details of fracture surface can clearly see the slip planes which are observed on the surface of the sheet near the fracture. Thus, these thin plates have the local plasticity, but either the plastic strain is inhomogeneous on the whole gage section of the sample or plastic strain propagates only in local band and continue to failure. This cross-section is not able to transfer the strength necessary for the strain of another section of tested sample.

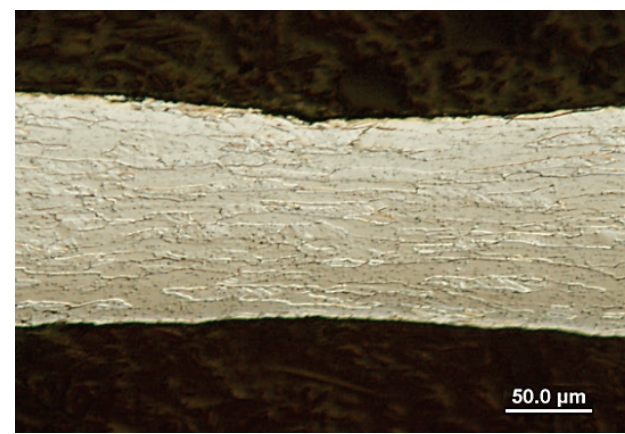

Figure 10 Microstructure of TS 480 BA, Sample No. 65

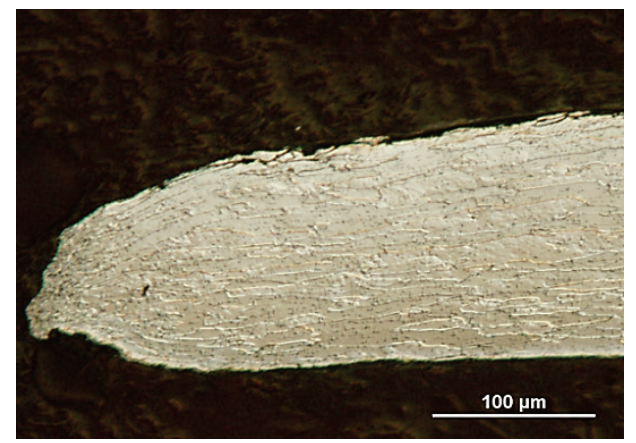

Figure 11 Microstructure of TS 480 BA, Sample No. 65

It was found that the local axial strain increased linearly and rapidly with time, indicating the propagation of the Lüders front over the area. A large amount of ferrite grains in this area are caused and experienced plastic deformation. For certain types of mild steels, knowledge indicate that the strain rate at the Lüders front was rather high and some dislocations unable to move at the high strain rate can continue to move at a slow velocity after the front has passed them. Some deformed ferrite grains may deform further and some undeformed ferrite grains may experience a delayed plastic deformation. Such actions result in creep deformation.

Inhomogeneity can be represented by changing the microgeometry of the surface of the material or inhomogeneity (inclusions, cracks caused by one particular reduction of grain boundaries). Failure of samples is probably initiated by the creation of the local neck in a certain place of the sample. This results in earlier failure and lower ductility. Thus, so narrow region cannot further transmit escalating loading and failure occurs just in this area.

\section{Conclusion}

The paper analyses loss of continuity and subsequent disruption of double-reduced thin plates during uniaxial and biaxial tensile test. TS 480 BA was selected for the testing. Based on the experiments' results we can conclude that batch annealing that is more expensive and longer than continuous annealing of the material did not result in higher elongation through uniaxial tensile test. The measured values of elongation in the direction of $0^{\circ}$ to rolling direction are very low (sample 57 less than 0,6 $\%$, sample 65 less than 1,9\%). Biaxial tensile test resulted in significantly higher elongation results measured in both 
sheets, despite in this case sheet is bent in more unfavorable way.

This difference is caused by high yield strength of the material. At the very beginning of plastic deformation in case of uniaxial tensile test the slip lines are generated; these exist in areas with inner inclusions in material. In these spots, as tension force increases, deformation is localized in the area of slip plains without spreading plastic deformation along the whole length of test sample. The test sample disrupts in this spot.

In case of biaxial tensile test the difference between yield strength $R_{\mathrm{p} 0,2}$ and $R_{\mathrm{m}}$ is higher. Plastic deformation occurs in various directions (suitably oriented grains), thus difference is not localized in its slip plain.

Based on the results we can conclude that uniaxial tensile test does not provide objective information regarding plastic properties of material. Biaxial tensile test is more suitable for DR tinplate lighter than $0,18 \mathrm{~mm}$. It provides more objective information on plastic properties of DR tinplate.

\section{Acknowledgements}

This article was provided and created with financial support of the projects VEGA No. 1/0872/14 and APVV0682-11.

\section{References}

[1] European Standard EN 10202:2001, Cold Reduced Tin mill Products-Electrolytic Tinplate and Electrolytic chromium/Cr Oxide Coated Steel, The European Standard Publications, Brussels, 2001.

[2] Spišák, E.; Slota, J.; Majerníková, J. Analýza priebehu deformácie jednoducho a dvakrát redukovaných obalových plechov. // Chemickélisty. 105, (2011), pp. 485-487.

[3] Spišák, E.; Slota, J.; Majerníková J.; Kaščák, L.; Malega, P. Inhomogeneous Plastic Deformation of Tinplates Under Uniaxial Stress state. // Chemickélisty. 106, (2012), pp. 537-540.

[4] Swift, H. W. Plastic Instability under Plane Stress. // Journal of the Mechanics and Physics of Solids. 1, (1), (1952), pp. 1-18. DOI: 10.1016/0022-5096(52)90002-1

[5] Hill, R. On Discontinuous Plastic States with Special Reference to Localised Necking in Thin Sheets. // Journal of the Mechanics and Physics of Solids. 1, (1952), pp. 1930. DOI: 10.1016/0022-5096(52)90003-3

[6] Marciniak, Z. Mechanics of Sheet Metal Forming. Plenum Press, New York, 1978.

[7] Zhang, J.; Jiang, Y. Lüders Bands Propagation of 1045 Steel under Multiaxial Stress State. // International Journal of Plasticity. 21, (2004), pp. 651-670. DOl: 10.1016/j.jplas.2004.05.001

[8] Zhang, J.; Jiang, Y. A Study of Inhomogeneous Plastic Deformation of 1045 Steel. // J. Eng. Mater. Technol. 126, (2004), pp. 164-172. DOI: 10.1115/1.1647125

[9] Makarov, P. V.; Schmauder, S.; Cherapanov, I. O.; Smolin, Yu. I.; Romanova, A. V.; Balokhonov, R. R.; Saraev, D. Yu.; Soppa, E.; Kizler, P.; Fischer, G.; Ludwig, S. Hu. M. Simulation of Elastic-plastic Deformation and Fracture of Materials at Micro-, Meso- and Macrolevels. // Theoretical and Applied Fracture Mechanics. 37, (2001), pp. 183-244. DOI: 10.1016/S0167-8442(01)00078-7

[10] Panin, V. E. (Ed.). Physical Mesomechanics of Heterogeneous Media and Computer-Aided Design of Materials. // Cambridge Interscience Publishing, (1998), pp. $1-40$.
[11] Panin, V. E.; Krotaev, A. D.; Makarov, P. V.; Kuznetsov, V. M. Physical Mesomechanics of Materials. // Izv. Vuzov. Fiz. 9, (1998), pp. 8-36. DOI: 10.1007/bf02508720

[12] Makarov, P. V. Physical Mesomechanics Approach in Simulation of Deformation and Fracture Processes. // Phys. Mesomech. 1, 1(1998), pp. 57-75.

[13] Makarov, P. V. Localized Deformation and Fracture of Polycrystals at Mesolevel. // Theoretical and Applied Fracture Mechanics. 33, (2000), pp. 23-30. DOI: 10.1016/S0167-8442(99)00048-8

[14] Doyama, M. Simulation of Plastic Deformation of Small Iron and Coper Single Crystals. // Nuclear Instruments and Methods in Physics Research Section B. 102, (1995), pp. 107-112. DOI: 10.1016/0168-583X(95)80125-6

[15] Machova, A. Dynamic Microcrack Initiation in $\alpha$-iron. // Materials Science and Engineering: A, (1996), pp. 279-289. DOI: 10.1016/0921-5093(95)10007-5

[16] Holian, B. L.; Ravelo, R. Fracture Simulations Using Largescale Molecular Dynamics. // Physical Review B. 51, 17(1995), pp. 11275-11288. DOI: 10.1103/PhysRevB.51.11275

[17] Inal, K.; Wu, P. D.; Neale, K. W. Instability and Localized Deformation in Polycrystalline Solids Under Plane-strain Tension. // International Journal of Solids and Structures. 39, (2002), pp. 983-1002. DOI: 10.1016/S0020-7683(01)002463

[18] Korotaev, A. D.; Tyumentsev, A. N.; Pinzhin, Yu. P. Activation of mesolevel Plastic Flow in High Strength Materials and Characteristic Types of Defective Structures. // Phys. Mesomech. 1, 1(1998), pp. 21-32.

[19] Romanova, V. A. Investigation of Relaxation Processes in Heterogeneous Media by Numerical Simulation. // Ph.D. Thesis, Institute of Strength Phys. and Mats. Sci., Tomsk, 1999.

[20] Makarov, P. V.; Romanova, V. A.; Smolin, I. Y. On a New Approach to Simulation of Plastic Flow at the Mesolevel. // Book of Abstracts of the Fifth Russian-Chinese International Symposium, Advanced Materials and Processes, Russia, 1999.

[21] Makarov, P. V.; Smolin, I. Y.; Prokopinsky, I. P. Localized Plastic Strain in Polycrystalline Materials with Hole and Notches. // Theoretical and Applied Fracture Mechanics, 29, (1998), pp. 11-22. DOI: 10.1016/S0167-8442(98)00011-1

[22] Švantner, P.; Bogdan, D.; Slota, J.; Spišák, E. Úprava zariadenia pre hydraulické vybul'ovanie za účelom zvýšenia výkonu hydraulického čerpadla. // Transfer inovácii. 24, (2012), pp. 103-106. http://www.sjf.tuke.sk/ transferinovacii/pages/archiv/transfer/24-2012/pdf/103106.pdf. (20.02.2013)

\section{Authors' addresses}

prof. Ing. Emil Spišák, CSc.

Technical University of Košice

Department of Technology and Materials

Mäsiarská 74, 04001 Košice

Slovak Republic

E-mail: emil.spisak@tuke.sk

\section{Ing. Janka Majerniková, PhD.}

Technical University of Košice

Department of Technology and Materials

Mäsiarská 74, 04001 Košice

Slovak Republic

E-mail: jana.majernikova@tuke.sk

Ing. Dávid Bogdan, PhD.

Technical University of Košice

Department of Technology and Materials

Mäsiarská 74, 04001 Košice

Slovak Republic

E-mail: david.bogdan@centrum.sk 
Ing. Tomáš Sleziak

Technical University of Košice

Department of Technology and Materials

Mäsiarská 74, 04001 Košice

Slovak Republic

E-mail: tomas.sleziak@tuke.sk

Ing. Marek Čižmár

U. S. Steel Košices r.o.

Vstupný areal U. S. Steel, 04454 Košice

Slovak Republic

E-mail: mcizmar@sk.uss.com 